\title{
CHANGING CONCEPTS IN THE SERO-DIAGNOSIS OF SYPHILIS : SPECIFIC TREPONEMAL ANTIBODY VERSUS WASSERMANN REAGIN*
}

\author{
BY \\ ROBERT A. NELSON Jr. \\ Bacteriology Division, Naval Medical Research Institute, Bethesda, Maryland, U.S.A.
}

Our work in the field of the bacteriology and immunology of syphilis has resulted in the discovery of two immunological phenomena which have helped to change the concepts of the sero-diagnosis of syphilis, and of the fundamental nature of the immune mechanisms which function in syphilitic infection.

I should like to emphasize that the work for which I have been responsible has been primarily concerned with experimental immunology, and only secondarily with syphilology per se. Virulent Treponema pallidum and the host-parasite relationship exemplified in syphilis have proved to be quite ideal as models for classical immunological phenomena. This fact has been found to be true of both the in vitro and the in vivo aspects of our work.

The work that I shall describe represented, in the main, a departure from a concept that had become quite prevalent in experimental syphilology, namely, that little could be accomplished in the field of the specific sero-diagnosis of syphilis without cultivation of treponemata. The failure to accomplish cultivation had proved to be too great a psychological and scientific stumbling block to many previous investigators, and research in syphilis had settled into a rather narrow channel of attempting to modify and perfect techniques for detecting Wassermann reagin. Unfortunately, this approach led to a stagnation in the experimental method, and also to a lack of progress in the field of sero-diagnosis because :

(1) it has not yet been possible to identify the antigen against which Wassermann reagin is an antibody ;

(2) the entire concept of the Wassermann reaction is based on non-specific principles.

The work, which was done in an attempt to obtain a synthetic medium with which virulent $T$. pallidum could be maintained in vitro for several days, was begun in my laboratory at the Johns Hopkins University School of Hygiene and Public Health in 1947. It had previously been possible to preserve

*Delivered to the Medical Society for the Study of Venereal Diseases, July 25, 1952. Received for publication September 4, 1952. the treponemata in vitro for only a few hours under physiological conditions.

After certain initial discoveries, such as the beneficial role of carbon dioxide (Nelson and Steinman, 1948), and of pyruvic acid and certain sulfhydryl compounds (Nelson, 1948), and provided extreme care was exerted in isolating treponemata early during the course of the syphilitic orchitis, it became possible to keep $T$. pallida actively motile and virulent in vitro in a relatively tissue-free suspension for 8 to 10 days.

The curves in Fig. 1 (opposite) demonstrate the biological pattern whereby treponemata live in vitro in our medium under physiological conditions.

The treponemata used in this experiment were isolated from rabbit testicular lesions, washed once in medium to remove all soluble testicular tissue juices, and then re-suspended in basal medium only. When no material other than phosphate buffer was added to the suspension (see Curve 5 of the righthand chart in Fig. 1) the treponemata died rapidly, only 18 per cent. remaining motile after $24 \mathrm{hrs}$. Addition to the suspension of an ultrafiltrate of normal ox blood serum in increasing increments (Curves 4 to 1) furnished additional nutrients, so that, with a final concentration of 20 per cent. serum ultrafiltrate, approximately 50 per cent. of the organisms remained motile and virulent for 5 days.

The isolation of the serum component which exerted this markedly beneficial effect on $T$. pallidum provided a very complex problem which was finally resolved in 1949 (Rice and Nelson, 1951) by the isolation of a crystalline compound, $\mathrm{C}_{12} \mathrm{H}_{22} \mathrm{O}_{10}$. $\mathrm{H}_{2} \mathrm{O}$, which would completely replace the survivalpromoting activity of serum. This compound has proved of great interest, since there is no record of such a compound in the chemical literature, and it has been found to be biologically' active at very low concentrations, and may fall into the vitamin or coenzyme group of compounds.

In the chart on the left are shown the percentages of treponemata which were observed to have active motility during 5 days' incubation in vitro in basal medium containing $\mathrm{C}_{12} \mathrm{H}_{22} \mathrm{O}_{10} \cdot \mathrm{H}_{2} \mathrm{O}$ but in the 
A. ASSAY WITH $\mathrm{C}_{12} \mathrm{H}_{22} \mathrm{O}_{10} \cdot \mathrm{H}_{2} \mathrm{O}$

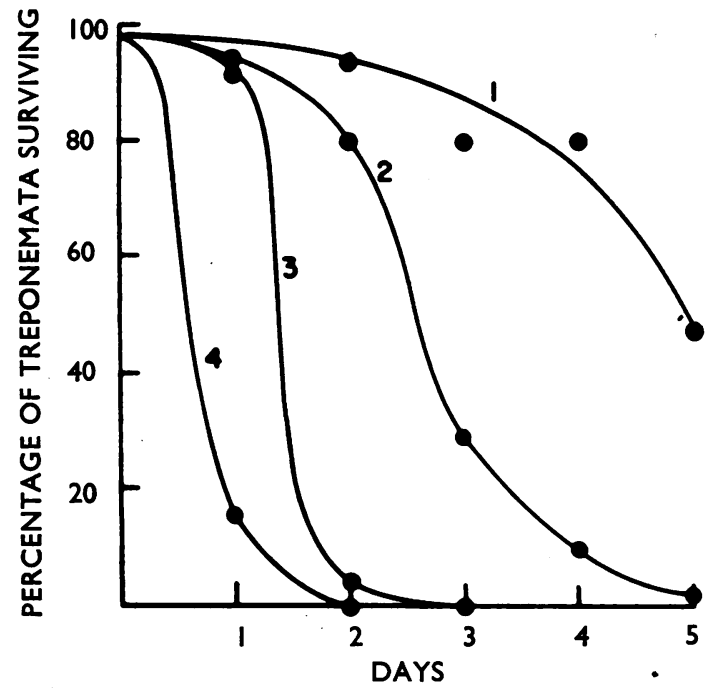

\begin{tabular}{|c|c|c|c|c|}
\hline Curve & 1 & 2 & 3 & 4 \\
\hline$\gamma$ per ml. & $75 \cdot 0$ & $15 \cdot 0$ & 3.0 & 0.6 \\
\hline
\end{tabular}

B. ASSAY WITH ULTRAFILTRATE OF BEEF SERUM

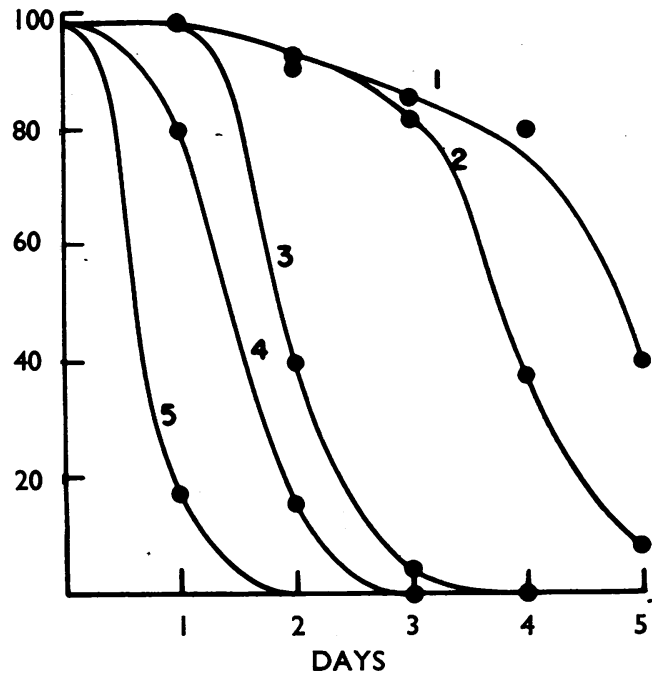

\begin{tabular}{|c|c|c|c|c|c|}
\hline Curve & 1 & 2 & 3 & 4 & 5 \\
\hline vol. per cent. & $20 \cdot 0$ & $4 \cdot 0$ & $0 \cdot 8$ & $0 \cdot 16$ & 0 \\
\hline
\end{tabular}

FIG. 1.-Comparative action of serum ultrafiltrate and $\mathrm{C}_{12} \mathrm{H}_{22} \mathrm{O}_{10} \cdot \mathrm{H}_{2} \mathrm{O}$ in promoting survival of $T$. Pallidum in vitro.

absence of serum or tissue juice. Unfortunately, time has not been available to continue this work which promised to be an important first step to an in vitro culture technique for virulent $T$. pallidum.

After one year of experimentation, we directed our efforts to determining whether specific antibody could be shown to exert any measurable effect on $T$. pallidum in vitro. As you all know, our first experiment resulted in the discovery in July, 1948 (Nelson and Mayer, 1949) of what is now called treponemal immobilizing antibody.

Early experiments showed that immobilizing antibody was separate and distinct from Wassermann reagin (Nelson and Mayer, 1949).

Fig. 2 shows the markedly different patterns of Wassermann reagin and immobilizing antibody which occur during the course of untreated infection in rabbits. The now well-established fact that immobilizing antibody reaches its peak level after 3 to 6 months' infection and

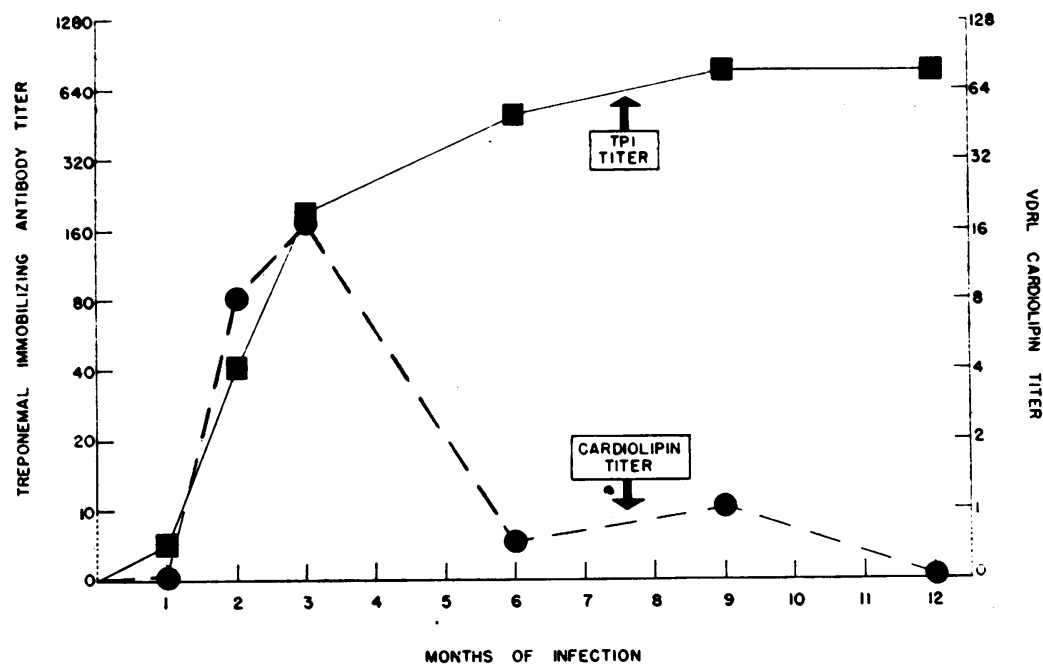

FIG. 2.-Titres of Wassermann and treponemal immobilizing antibodies in untreated experimental rabbit syphilis. thereafter remains at high levels in untreated animals was the first suggestive evidence that immobilizing antibody might play a role in immunity to reinfection. It was soon found that the appearance of immobilizing antibody was highly specific for syphilitic infection. Thus, the antibody was believed to be directed against an antigen which occurred 
exclusively in the virulent treponemata. Moreover, the in vitro action of the antibody was treponemicidal and logically would appear to play a part in preventing re-infection.

Further evidence of the relationship of immobilizing antibody to the immune state was first obtained in 1950 (Turner and Nelson, 1950). A summary of one of the more important experiments is shown in Fig. 3. Three groups of animals were infected

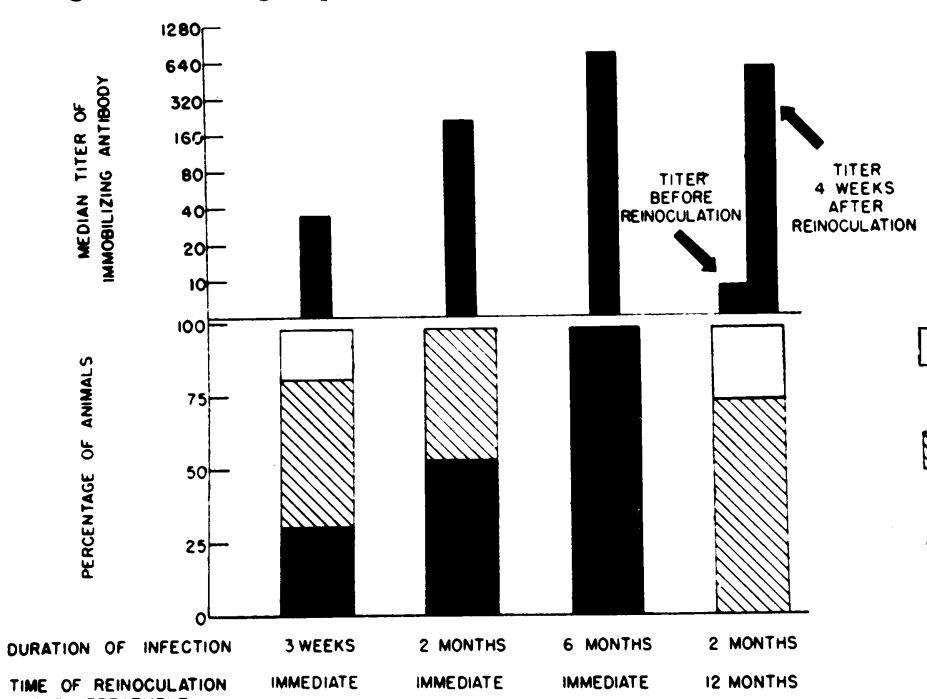

TIME OF REINOCULATION

FIG. 3.-Relationship of immobilizing antibody to immunity in experimental syphilis.

2 months', and 6 months' infection. Upon re-inoculation of all of the animals and of some normal control animals with 2,000 treponemata, an approximately direct relationship between the level of antibody in the serum and the degree of resistance to re-inoculation was found.

During these experiments the phenomenon shown in Fig. 4 was observed. With a group treated after 2 months of syphilitic infection, antibody titre fell slowly but steadily to barely detectable levels during the subsequent 12 months; but 3 to 4 weeks after re-inoculation of these animals with 2,000 treponemata, the antibody titre made a rapid and striking increase. At this time, antibody attained a level not ordinarily reached for 4 to 6 months in normal animals inoculated with the same number of organisms. This NON-PROGRESSIVE accelerated antibody LESIONS: PARTIAL
IMMUNITY classical anamnestic

NO LESIONS COMPLETE IMMUNITY with a large dose of treponemata, and then given curative treatment with penicillin after 3 weeks',

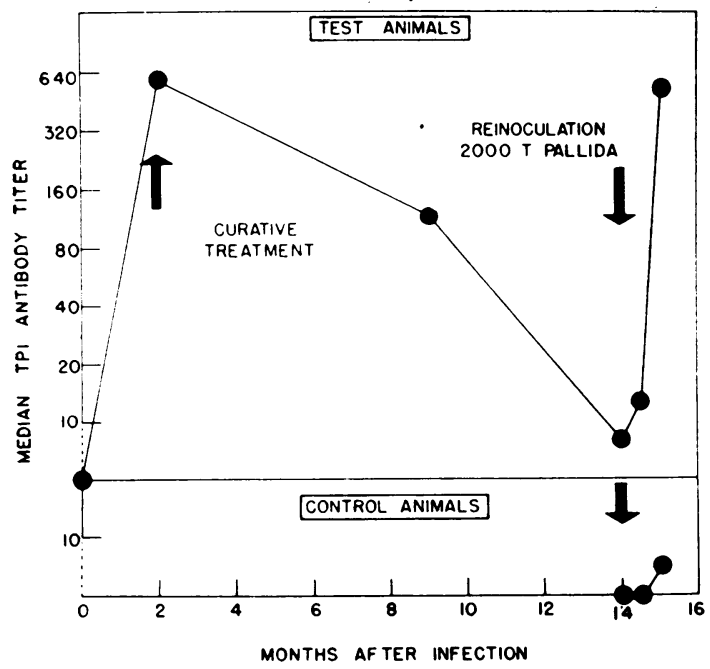

FIG. 4.-Development of immobilizing antibody in experimental syphilis following initial inoculation and re-inoculation. lesions. The lesions did not progress to the typical large ulcerating chancre, but rather began to recede and became free of treponemata within a few days after the antibody level had risen.

It is suggested that this anamnestic phenomenon may be of fundamental importance in immunity in syphilis. The occurrence of the " booster" response must now be studied carefully in relation to dosage, time, and other variables. It is possible that this phenomenon may be an important factor in the mechanics of the so-called "permanent immunity" in syphilis. The concept that immunity persists unchanged, even after treatment and supposed cure, originated from studies of resistance to re-infection performed by classical re-inoculation techniques. Since the occurrence, or lack of occurrence, of the lesion after re-inoculation is an endpoint measurement only, no insight into the mechanics of resistance may be obtained by in vivo measurements. It is also important to emphasize at this time, that the practice has become popular in many laboratories, whereby the re-inoculation of a measured number of $T$. pallidum into previously infected animals is termed a "quantitative" measurement of immun- 
ity. It would seem that this is a most liberal, if not dangerous, interpretation of the term "quantitative". It is obvious that a very substantial number of variables may influence the sequence of events which take place in re-inoculation experiments. For example, it has been possible to show that under certain conditions animals may show an equal, or even greater, immunity to large than to small challenge inocula.* This paradoxical situation was demonstrated in a group of animals infected and cured, and then subdivided so that half of the animals received a re-inoculation of 500 treponemata, and the other half one of 5,000. An approximately equal number of lesions appeared with both inocula. It is my impression that an anamnestic response in the animals receiving the larger inoculum may have been the basis for this unusual effect. Nevertheless, it is wise to be realistic and to recognize the limitations of re-inoculation of organisms into a living host as a quantitative procedure.

With reference to the entire question of the relationship between the immobilizing antibody and immunity, it should be noted that no definitive answer can be given at this time. Certain data have been accumulated by Magnuson in the United States, which indicates that immobilizing antibody may not be directly associated with immunity.

In general, the data currently available on the TPI test in human syphilis is similar to the data cited for experimental rabbit syphilis.

Fig. 5 demonstrates the median titre found in the four stages of syphilitic infection in human beings (solid circles). The pattern is clearly established wherein antibody develops slowly during early infection, increases during the secondary stage,

* Nelson, R. A., unpublished experiments. reaches the highest levels during the latent stage, and, in general, remains at high levels during the late phases of infection. Although it is true that quantitative tests have been performed on only a small number of patients, there has been no evidence that patients who develop late symptomatic lesions have a pattern of antibody different from that in those in whom infection remains latent.

With reference to this last point, preliminary studies have been performed on the use of the TPI test in the identification of strains of $T$. pallidum in experimental animals (Khan and others, 1951). Of five strains examined, one showed a difference in cross-immobilizing reactivity from the other four. It is suggested that one future application of the TPI test may be in the search for strains showing a tendency to cause lesions of specific tissues.

The influence of treatment on immobilizing antibody titre in human syphilis is also shown in Fig. 5. Post-treatment titres are designated by the hollow circles. The rate of decline in titre after therapy for primary and secondary syphilis was essentially the same as that noted in a group of rabbits treated for experimental infection. However, a striking difference was noted in patients with latent and late symptomatic infection. No significant decline in titre occurred within 2 years after treatment.

This absence of decline in patients with late infection poses the interesting question whether therapy is effective in eliminating long standing infection. On the other hand, two possibilities exist : the first that therapy is actually successful in destroying all spirochaetes, but that the tissues of the host have become "sensitized" and continue to produce antibody even though the micro-organism is eliminated; the second that the micro-organism
FIG. 5.-Effect of penicillin therapy on titre of treponemal immobilizing antibody in human syphilis.

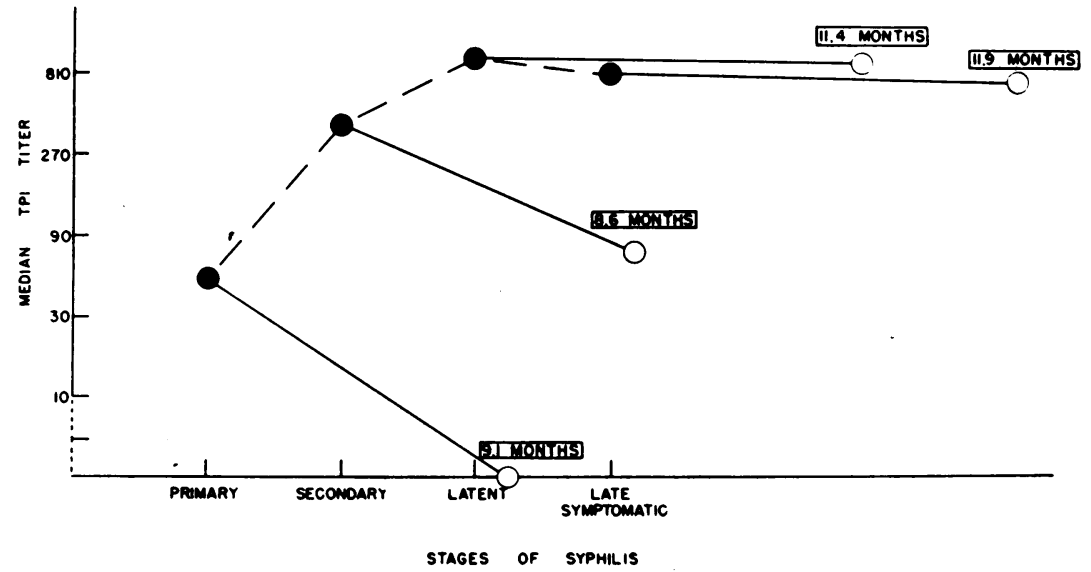


is killed, or destroyed as a pathogenic entity, but that sufficient soluble antigen remains in the tissue of the host to stimulate antibody production.

Unfortunately, it does not appear that this problem can be solved by animal experimentation, since antibody titre has receded after treatment in all animals examined to date.

Nevertheless, the preceding data indicate that a fall of immobilizing antibody to zero after therapy for early syphilis may be an index of cure. If continued experiments verify this fact, a valid scientific criterion for cure may be realized. Such would be most valuable, since the presently employed criterion of the reversal of titre of reagin tests appears.to be a purely empirical choice. It is, perhaps, unscientific to utilize the disappearance of Wassermann reagin as a criterion for cure, when it is not possible to prove that this reagin is an antibody against the organism causing syphilis.

One interesting set of data bearing on this is shown in Fig. 6. Three groups of rabbits were inoculated with treponemata and allowed to go untreated for one month : one group was allowed to progress as "untreated controls"; a second was given curative doses of penicillin over an 8-day period and designated as "cured controls"; a third was given small doses for only 4 days.

TPI titres were performed on these rabbits at varying times for 5 months. The titre progressed to, and remained at, high levels of approximately 600 units in the " untreated controls", and fell to zero after 2 to 3 months in the " cured controls".

The titre of immobilizing antibody in some of the animals treated with small doses of penicillin behaved similarly to those in the "cured controls". Transplantation of lymph nodes from these animals into normal rabbits yielded negative results, and indicated that therapy had been effective.

However, in two animals, the pattern of immobilizing antibody and of Wassermann reagin were as shown in Fig. 6. Despite the fact that reagin titre declined to, and remained at, negativity at the fifth month, there was a significant restimulation of immobilizing antibody 4 weeks after therapy. Although this elevation suggested that cure was not effected, the transplantation of lymph nodes 6 weeks after therapy yielded negative results. However, 4 months after treatment, treponemata were demonstrated by positive lymph-node transfer, and "relapse" or treatment-failure was proved.

Thus, a syndrome of Wassermann-negative, asymptomatic relapse was demonstrated. Since the experiment was preliminary and was terminated after only 5 months, it is not known whether the treatment-failure would have been reflected by the reappearance of Wassermann reagin at a later date. However, the failure of penicillin to effect a cure in these animals was detected after one month, before conventional methods of assaying relapse, e.g. by the transfer of lymph nodes, Wassermann reagin, or clinical signs.

A final aspect of the influence of treatment on immobilizing antibody may be seen in Table $I . *$ Here 256 patients who, several years previously, had been proved to have acquired late syphilis and were

* Unpublished data of Dr. Joseph Earle Moore, Baltimore, Maryland, U.S.A.

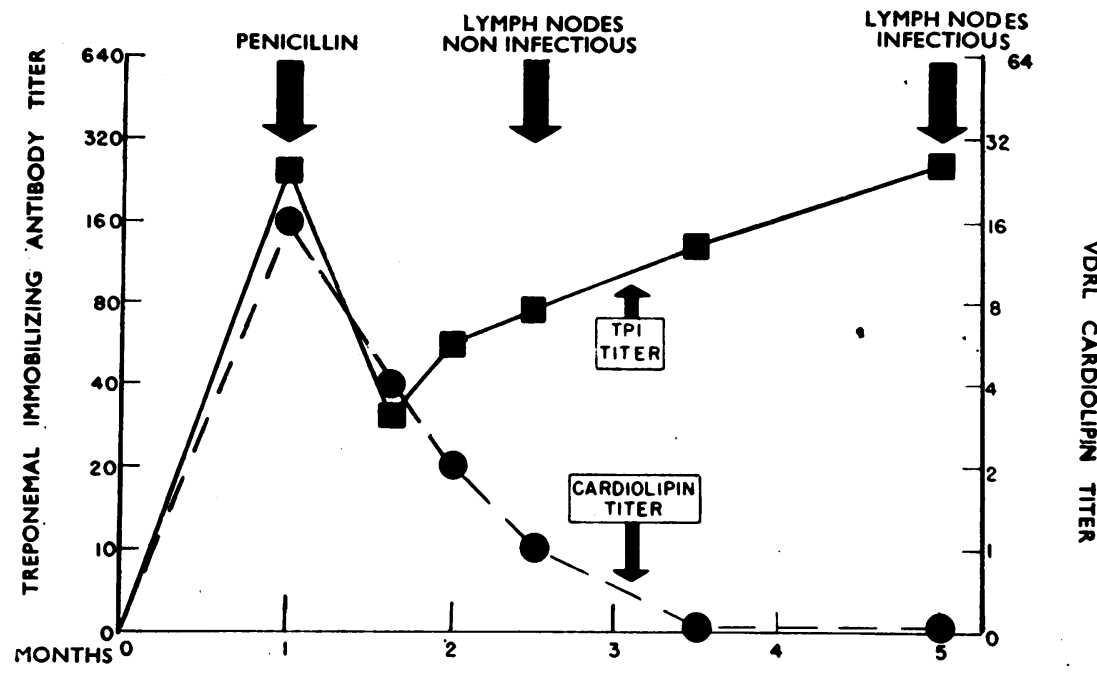

Fig. 6.-Titres of Wassermann and of treponemal immobilizing antibodies following subcurative penicillin treatment in experimental rabbit syphilis. 
TABLE I

TPI TEST IN TREATED LATE SYPHILIS

Diagnosis based on definite clinical evidence and/or abnormal cerebrospinal fluid

\begin{tabular}{c|c|c|c}
\hline $\begin{array}{c}\text { Number of } \\
\text { Patients }\end{array}$ & $-\begin{array}{c}\text { TPI Test } \\
\text { Positive }\end{array}$ & Doubtful & Negative \\
\hline 256 & 246 & 3 & 7 \\
\hline$(97 \cdot 3 \%)$ & $\begin{array}{c}7 \\
(2 \%)\end{array}$ \\
\hline
\end{tabular}

treated, were subjected to TPI tests. In 246 patients (97 per cent.) the TPI test remained strongly positive, indicating that therapy does not ordinarily cause reversal of the qualitative test even up to 40 years after treatment.

The TPI test has also been applied to certain difficult diagnostic problems of clinical syphilis. It seems likely that standard tests for syphilis (reagin tests), by whatever modification of the complementfixation or flocculation techniques, are identical in that they detect the same antibody, Wassermann reagin. With the widespread mass blood testing which has become popular in the last decade, there has been an abundance of evidence that reagin is present in the serum of most, if not all, normal persons. It may appear in considerable quantity in the serum under the influence of various diseases other than syphilis. Therefore, in a great number of persons with positive tests for syphilis, but with no signs or symptoms, it has been impossible to establish or to exclude a diagnosis of syphilis.

While the evidence of the specificity of the TPI antibody was most impressive in initial studies on patients at the Johns Hopkins Hospital (Nelson and others, 1950), several diseases noted for their high incidence of false positive reagin tests remained to be investigated. Of primary importance in this group was leprosy.

In 1950, seventy patients at the leprosarium in Carville, Louisiana, U.S.A. were selected for study. Apart from the fact that all were stated to have no history, signs, or symptoms of syphilis, no strict criteria were followed regarding past serologic tests, treatment, race, etc. Serum from each patient was tested with the VDRL cardiolipin flocculation test, a complement-fixation test using cardiolipin antigen, and the TPI test. Of the seventy sera, thirteen were negative, and 57 were positive with either one or both of the tests with cardiolipin antigen. Of the thirteen patients with negative reagin tests, all were negative for immobilizing antibody, except one, which was doubtful. Of the remaining 57 cardiolipin-positive sera, only eleven showed reactivity with the TPI test.

Thus, an incidence of 16 per cent. reactive TPI tests compares favourably with previous epidemio- logical studies on this patient population which indicated that between 15 to 20 per cent. might be estimated to have had syphilitic infection.

Dr. C. W. Chacko, working at the WrightFleming Institute in London, found similar results in 24 leprosy cases examined by the TPI test.

In addition, no positive TPI tests have been found either in normal persons or in non-syphilitic patients with transient false positive reagin tests due to infectious mononucleosis, atypical pneumonia, malaria, measles, chicken pox, and a variety of other acute infectious diseases.

Of perhaps greater importance to the clinician have been the results of two studies of presumed normal individuals and of persons suffering with chronic diseases such as tuberculosis, lupus erythematosis disseminatus, peri-arteritis nodosa, etc., on whose sera repeatedly positive standard serologic tests had been obtained often over many years.

The results of the first study are shown in Table II. These 300 patients were selected from the private practice of Dr. Joseph Earle Moore ; none had a history of signs or symptoms of syphilis, and all had positive standard tests for syphilis, usually over a period of many years. All were white, and in the middle or upper socio-economic class, and many had been treated previously for syphilis on the basis of the positive reagin test.

\section{TABLE II}

INCIDENCE OF CHRONIC BIOLOGIC FALSE POSITIVE REACTIONS AND LATENT SYPHILIS IN THE PRIVATE PRACTICE OF DR. J. E. MOORE

\begin{tabular}{c|c|c}
\hline $\begin{array}{c}\text { No. of Patients } \\
\text { with Positive } \\
\text { Reagin Tests }\end{array}$ & $\begin{array}{c}\text { Positive } \\
\text { (Latent Syphilis) }\end{array}$ & $\begin{array}{c}\text { Tegative } \\
\text { (False Positive } \\
\text { Reagin Tests) }\end{array}$ \\
\hline 300 & $\begin{array}{c}164 \\
(54 \cdot 7 \%)\end{array}$ & $\begin{array}{c}136 \\
(45 \cdot 3 \%)\end{array}$ \\
\hline
\end{tabular}

Of the 300 patients, 136 (45 per cent.) were negative with the TPI test. Although some had clinical syndromes which had been adjudged to be responsible for a false positive reagin test, the remainder appeared to be normal on physical examination.

Dr. Moore felt that the high incidence of negative TPI tests was of such critical importance that additional laboratory and clinical examinations were scheduled on all TPI negative patients. To date, 51 patients have been thoroughly studied (Table III, overleaf). Of these, 31 (60.8 per cent.) were diagnosed as having recognizable disease syndromes ; fourteen ( $27 \cdot 4$ per cent.) were clinically normal but had distinctly abnormal laboratory tests (other than positive reagin tests); only six (11.7 
TABLE III

CAUSES OF CHRONIC FALSE POSITIVE REAGIN TESTS IN PRIVATE PATIENTS OF DR. J. E. MOORE ; ALL PATIENTS NEGATIVE WITH TPI TEST

\begin{tabular}{|c|c|c|c|c|c|c|}
\hline \multirow{2}{*}{$\begin{array}{l}\text { Total } \\
\text { No. of } \\
\text { Patients }\end{array}$} & \multicolumn{2}{|c|}{ Diagnosis } & \multicolumn{2}{|c|}{$\begin{array}{l}\text { Provisional } \\
\text { Diagnosis }\end{array}$} & \multirow{2}{*}{$\begin{array}{c}\text { Clinically } \\
\text { Normal } \\
\text { but with } \\
\text { Abnormal } \\
\text { Laboratory } \\
\text { Tests }\end{array}$} & \multirow{2}{*}{$\begin{array}{c}\text { Normal } \\
\text { Except } \\
\text { for } \\
\text { Positive } \\
\text { Reagin } \\
\text { Tests }\end{array}$} \\
\hline & $\begin{array}{l}\text { Collagen } \\
\text { Disease }\end{array}$ & Other & $\begin{array}{l}\text { Collagen } \\
\text { Disease }\end{array}$ & Other & & \\
\hline 51 & $\begin{array}{l}5 \\
(15 \cdot 7\end{array}$ & $\%^{3 *}$ & 21 & $\%)^{2 \dagger}$ & $\begin{array}{c}14 \\
(27 \cdot 4 \%)\end{array}$ & $\begin{array}{c}6 \\
(11 \cdot 7 \%)\end{array}$ \\
\hline
\end{tabular}

*Sarcoid, Hodgkin's disease, and Gaucher's disease, 1 each. †Sarcoid in both.

per cent.) were negative both clinically and with the other laboratory tests employed. These data appear to be of major importance in the clinical management of patients found to have long-term positive standard serological tests for syphilis with a negative TPI test. It is a distinct warning that these false positive reactors may have disease syndromes potentially more serious than syphilis. The high specificity of the TPI test has given the opportunity to identify the false positive reagin test.

A second study has been performed in the United States Navy. All persons found to have a positive reagin test (usually the standard Kahn flocculation test) but in whom there were no signs or symptoms of infection, were required to have a TPI test (Table IV).

\section{TABLE IV}

UNITED STATES NAVY TREPONEMAL IMMOBILIZATION TEST PROGRAM

Location-Naval Medical Research Institute, NNMC, Bethesda, Md. Duration-12 months : 9 April, 1951 , to 19 March, 1952.

Sera received-1,224

\begin{tabular}{|c|c|c|c|c|c|}
\hline \multirow{3}{*}{$\begin{array}{l}\text { Result of } \\
\text { TPI Test }\end{array}$} & & \multicolumn{4}{|c|}{674 Sero-Positive Patients } \\
\hline & & \multicolumn{2}{|c|}{ Untreated (529) } & \multicolumn{2}{|c|}{ Treated (145) } \\
\hline & & No. & $\%$ & No. & $\%$ \\
\hline $\begin{array}{ll}\text { Positive } & \ldots \\
\text { Negative } & \cdots \\
\text { Doubtful } \\
\text { No Valid } & \text { Test }\end{array}$ & $\begin{array}{l}\because \\
\because \\
\therefore\end{array}$ & $\begin{array}{r}274 \\
224 \\
0 \\
31\end{array}$ & $\begin{array}{r}51 \\
42 \\
0 \\
7\end{array}$ & $\begin{array}{r}108 \\
25 \\
0 \\
12\end{array}$ & $\begin{array}{r}74 \\
17 \\
0 \\
9\end{array}$ \\
\hline
\end{tabular}

From April, 1951, to March, 1952, 1,224 sera were tested. Of 529 untreated patients, 224 (or 42 per cent.) were negative with the TPI test ; and of 145 patients who had received penicillin therapy in the recent past because of a positive Kahn test 25, (17 per cent.) were negative with the TPI test.

In an attempt to discern a cause of the false positive Kahn test, the data in Table V were obtained. Except for a slightly greater incidence of acute infectious diseases in patients with negative TPI tests, there were no significant differences between those with negative and those with positive TPI tests. In all, 82 per cent. of the TPI-positive, and 74 per cent. of the TPI-negative patients had in their history no known factors responsible for the occurrence of false positive standard tests for syphilis. In general, these patients were discovered to have a positive reagin test on routine examination, e.g., during routine induction examination, annual physical examination, routine physical examination for discharge from service, etc.

TABLE V

POSSIBLE CAUSES OF FALSE POSITIVE REAGIN TESTS IN 498 SERO-POSITIVE UNTREATED PATIENTS IN THE U.S. NAVY

\begin{tabular}{|c|c|c|c|c|}
\hline \multirow{3}{*}{$\begin{array}{c}\text { Possible Causes } \\
\text { of False Positive } \\
\text { Reagin }\end{array}$} & \multicolumn{4}{|c|}{ TPI } \\
\hline & \multicolumn{2}{|c|}{ Positive (274) } & \multicolumn{2}{|c|}{ Negative (224) } \\
\hline & $\begin{array}{l}\text { No. of } \\
\text { Patients }\end{array}$ & $\%$ & $\begin{array}{l}\text { No. of } \\
\text { Patients }\end{array}$ & $\%$ \\
\hline Immunization* $\quad \ldots$ & 33 & 12 & 31 & 13 \\
\hline $\begin{array}{c}\text { Acute Infectious } \\
\text { Disease }\end{array}$ & 9 & 3 & 20 & 9 \\
\hline Chronic Disease .. & 9 & 3 & 9 & 4 \\
\hline No Known Cause. . & 223 & 82 & 164 & 74 \\
\hline
\end{tabular}

*Includes all patients given routine immunizations from 1 to 28 days preceding the first positive standard serologic test for syphilis.

These studies on two separate and distinct patient populations indicate the magnitude of the problem of false positive standard tests for syphilis, whether technical or biological, chronic or acute. It would seem desirable that a universal programme be adopted whereby the TPI test, or some modification thereof, serve as a final criterion for diagnosis in patients suspected of having latent syphilis because of positive reagin tests.

\section{Adhesion-Disappearance Phenomenon}

In November, 1950, we first began experiments designed to demonstrate in vitro phagocytosis of $T$. pallidum. This work was begun for two main reasons : first, the logical analysis of immunity in syphilis made me, along with many previous investigators, think that phagocytosis ought to occur but had probably never been proved because of some technical difficulty; second, an attack on this problem seemed feasible since techniques developed during the work on immobilizing antibody yielded tissue-free suspensions of treponemata ideally suited for phagocytosis experiments. Our first experiments were performed with techniques similar to those of Maaløe (1946).

In brief, the technique consisted of mixing tissuefree suspensions of treponemata, either living or heat-killed, with syphilitic serum. The mixture was 
TABLE VI

In Vitro ADHESION-DISAPPEARANCE PHENOMENON

1. Essential Role of Specific Antibody

\begin{tabular}{|c|c|c|}
\hline $\begin{array}{l}\text { Sensitizing } \\
\text { Serum }\end{array}$ & \multicolumn{2}{|c|}{$\begin{array}{l}\text { No. of Treponemata remaining (per } 50 \text { fields) } \\
\text { after Exposure to Blood* }\end{array}$} \\
\hline $\begin{array}{l}\text { Normal } \\
\text { Syphilitic }\end{array}$ & \multicolumn{2}{|c|}{$\begin{array}{r}94 \\
1\end{array}$} \\
\hline \multicolumn{3}{|c|}{$\begin{array}{l}\text { 2. Essential Role of Heat-Labile Factor of Norman Serum, probabl. } \\
\text { Complement }\end{array}$} \\
\hline \multirow{2}{*}{$\begin{array}{l}\text { Sensitizing } \\
\text { Serum }\end{array}$} & \multicolumn{2}{|c|}{$\begin{array}{l}\text { No. of Treponemata remaining (per } 50 \text { fields) } \\
\text { in Blood Cells washed in Hank's Solution }\end{array}$} \\
\hline & $\begin{array}{l}\text { Resuspended in } \\
\text { Heated Serum }\end{array}$ & $\begin{array}{l}\text { Resuspended in } \\
\text { Fresh Serum }\end{array}$ \\
\hline $\begin{array}{l}\text { Syphilitic } \\
\text { Rabbit }\end{array}$ & 136 & 0 \\
\hline
\end{tabular}

then exposed to heparinized whole blood, freshly collected from a normal individual. After incubation at $37^{\circ} \mathrm{C}$., there was a striking disappearance of the treponemata from the mixtures when examined directly, or from the supernatant fluid obtained after the mixtures were gently centrifuged to remove the blood cells (Table VI). No such disappearance occurred with treponemal suspensions mixed with non-syphilitic serum and then exposed to whole blood.

Preliminary studies established clearly that specific antibody was essential in the "disappearancephenomenon ". By means of absorption techniques it was possible to prove that the antibody responsible was distinct and separate from Wassermann reagin. As yet, it has not been possible to determine the relationship of this antibody to, or its possible identity with, treponemal immobilizing antibody.

The preliminary investigations also clearly established that a heat-liable component of normal serum, presumably complement, was essential for the reaction to occur (Table VI).

Early work suggested that this phenomenon was due to phagocytosis of the sensitized organisms by leucocytes, in the presence of complement, in the classically described sequence of events. However, the sequence of events and the main factors involved in this reaction have been studied. The conclusions are shown in Table VII. It appears likely that these data represent the key to an understanding of this complex, but interesting, immunological phenomenon.

The results of this investigation to the present time indicate that:

(1) The immunological phenomenon involving the " disappearance" of sensitized $T$. pallidum from suspensions containing whole blood is a complicated four-step reaction, involving specific antibody,
TABLE VII

THEORETICAL STEPS IN REACTION OF VIRULENT T. Pallidum in vitro WITH ANTIBODY, COMPLEMENT, AND NORMAL HUMAN BLOOD CELLS

\begin{tabular}{|c|c|c|}
\hline 1 & $\mathrm{TP}+\mathrm{Ab} \rightarrow \mathrm{TP}-\mathrm{Ab}$ & $\begin{array}{l}\text { Sensitization } \\
\text { (a) Antibody is distinct } \\
\text { from Wassermann Re- } \\
\text { agin }\end{array}$ \\
\hline 2 & $\underset{\mathrm{TP}-\mathrm{Ab}+\mathrm{C}^{\prime} \rightarrow \mathrm{TP}-\mathrm{Ab}}{\mathrm{C}^{\prime}}$ & $\begin{array}{l}\text { Complement Fixation } \\
\text { (a) Active component is } \\
\text { heat labile fraction of } \\
\text { normal serum, presum- } \\
\text { ably } C^{\prime}\end{array}$ \\
\hline 3 & $\underset{C^{\prime}}{\mathrm{TP}-\mathrm{Ab}+\mathrm{RBC} \rightarrow \mathrm{TP}-\mathrm{I}}=\underset{\mathrm{C}^{\prime}}{\mathrm{Ab}-\mathrm{RBC}}$ & $\begin{array}{l}\text { Adhesion Phenomenon } \\
\text { (a) Adhesion does not } \\
\text { occur with platlets or } \\
\text { with leucocytes } \\
\text { (b) Adhesion does occur } \\
\text { with lysed erythrocytes } \\
\text { (ghost cells) }\end{array}$ \\
\hline 4 & $\begin{array}{c}\mathrm{TP}-\mathrm{Ab}-\mathrm{RBC}+\mathrm{WBC} \\
\mathrm{C}^{\prime} \quad \rightarrow \text { Total Disappearance }\end{array}$ & $\begin{array}{c}\text { Disappearance Phenomenon } \\
\text { (a) Probable phagocyto- } \\
\text { sis? } \\
\text { (b) } \mathrm{TP}-\mathrm{Ab}+\mathrm{WBC} \rightarrow \mathrm{No} \\
\text { ! disappearance } \\
\mathrm{C}^{\prime} \text {. }\end{array}$ \\
\hline
\end{tabular}

complement, red blood cells, and, finally, white blood cells. It is suggested that the last step is phagocytosis.

(2) A definite immunological role of erythrocytes in this reaction has been established. To my knowledge, no previous evidence has been described of red blood cell reactivity in such a specific immunological phenomenon. While it is well known that certain viruses and many other materials have been demonstrated to be absorbed onto the surface of erythrocytes, it should be re-emphasized that nonsensitized $T$. pallida do NOT adhere to the red cell ; and, further, that the adherence of sensitized $T$. pallida to the red cell appears to be specific, in that the sensitized treponema will NOT adhere to other cells, such as white blood cells, platelets, and yeast cells.

The mechanism of the action of the red cells is under investigation.

(3) While it has been possible to utilize the occurrence of the adhesion-disappearance phenomenon in a preliminary evaluation of its use as a diagnostic procedure, the complexity of the four steps of the reaction suggests that considerable experience in the purely investigative aspects of the phenomenon must be obtained before it can be used as clinical test.

\section{Conclusion}

Perhaps the lesson to be learned from these accomplishments can be summarized by the statement that the approach used was simple. The key to the discovery of immobilizing antibody lay in the ability to sustain the treponemata in vitro for periods long enough for the action of the antibody 
to become manifest. The key to the discovery of the disappearance phenomenon lies in :

(1) the ability to obtain from the rabbit tissue-free suspensions of organisms which were also free of small amounts of antibody,

(2) the use of indirect techniques for measuring antibody action, rather than the staining of leucocytes used in classical phagocytosis experiments.

Perhaps the key to the cultivation of $T$. pallidum will also be found to lie in some such simple principle.

The gratitude of the author is expressed to Dr. F. A. Johansen and Sister Hilary Ross of the U.S. Marine
Hospital for their cooperation in obtaining sera from the leprosarium at Carville, La.

\section{REFERENCES}

Khan, A. S., Nelson, R. A., and Turner, T. B. (1951). Amer. J. Hyg., 53, 296.

Maaløe, O.(1946). "On the Relation between Alexin and Opsonin." Munksgaard, Copenhagen.

Nelson, R. A. (1948). Amer. J. Hyg., 48, 120.

-, and Mayer, M. M. (1949). J. exp. Med., 89, 369.

, and Steinman, H. G. (1948). Proc. Soc. exp. Biol., N.Y., 68, 588.

—, Zheutlin, H. E. C., Diesendruck, J. A., and Austin, P. G. M. (1950). Amer. J. Syph., 34, 101.

Rice, F. A. H., and Nelson, R. A. (1951). J. biol. Chem., 191, 35.

Turner, T. B., and Nelson, R. A. (1950). Trans. Ass. Amer. Phys., $63,112$. 